\title{
Parenting of people with visual disabilities as an interdisciplinary context of contemporary special education
}

\author{
"(...) Blind girls want to get married, \\ have their own families and children, similarly to blind men"2
}

\begin{abstract}
Magdalena Wałachowska, Parenting of people with visual disabilities as an interdisciplinary context of contemporary special education. Interdisciplinary Contexts of Special Pedagogy, no. 26, Poznań 2019. Pp. 163-190. Adam Mickiewicz University Press. ISSN 2300-391X. e-ISSN 2658-283X. DOI: https:// doi.org/10.14746/ikps.2019.26.08

The aim of the article is to present the issues of parenting of people with visual disabilities as a factor that dynamizes development, against the background of selected interdisciplinary contexts (psychological, functional, pedagogical). The sphere of personality-emotional development was presented through a psychological context. The functional sphere is represented by the functional context, and the development in the cognitive area has been based on the pedagogical context. The study was summarized indicating areas requiring scientific penetration in the social context of the functioning of the parental practice of the blind and visually impaired. The text was based on the method of descriptive and critical literature analysis.
\end{abstract}

KEY WORDS: a person with visual disability, parenting, interdisciplinary contexts

${ }^{1} \mathrm{PhD}$ in the humanities in the field of education, assistant professor in the Department of Fundamentals of Special Education of the Maria Grzegorzewska University, mwalachowska@aps.edu.pl

${ }^{2}$ M. Oczkowska, Sytuacja niewidomej kobiety. A typescript of the paper presented during the Conference of the Polish Association of the Blind, PZN, Muszyna 1958, pp. 7-8. 


\section{Introduction}

"They [disabled people, author's note] have always made friends, loved, started families, gave birth to children, undertaken the effort of raising them and given them their love. Without special permits, instructions or support. Just by simply accepting the joys, concerns and challenges of human existence" ${ }^{3}$ Performing a role in the family is one of the central needs ${ }^{4}$, that a person undertakes in the period of middle adulthood, despite numerous dangers arising from contemporary social changes affecting families..$^{5}$ Blind and partially sighted people, having additional obstacles to overcome, also have a strong natural motivation to start their own family. The aim of this choice is to achieve emotional and psychological interdependence, a close intimate relationship by stabilizing sexual life,

${ }^{3}$ D. Podgórska-Jachnik, Problem ojcostwa w kontekście niepetnosprawności $z$ perspektywy naukowej, [in:] Ja ojciec, ed. M. Rydzewski, Wydawnictwo Fundacji „Otwórz Oczy”, Warsaw 2013, p. 4; after: B. Górnicka, Pomimo niepetnosprawności... - wybrane aspekty rodzicielstwa w różnych fazach funkcjonowania rodziny z problemem niepetnej sprawności dziecka lub rodzica, [in:] Rodzicielstwo w różnych fazach rozwoju rodziny, ed. J. Brągiel, B. Górnicka, Wydawnictwo Uniwersytetu Opolskiego, Opole 2017, p. 73.

${ }^{4}$ R. Ossowski, Ksztattowanie obrazu wtasnej sytuacji $i$ siebie u inwalidów wzroku w procesie rehabilitacji, Wydawnictwo Uczelniane WSP Bydgoszcz, Bydgoszcz 1982, p. 30 .

${ }^{5}$ Changes and threats to the contemporary family include: dominance of the elementary family as a separate economic unit, blurring of relationships and contacts with the extended family; decrease in elderly people's influence; revolution in malefemale relations, mass entry of women into the labour market, devaluation of family life, pessimistic attitude towards the institution of marriage; development of medicine serving, among others, to sanction contraceptives and abortion; disintegration of the traditional family model by the promotion of gender ideology and legalization of homosexual partnerships; changes in sexual ethics; promotion of mass culture popularizing a consumer lifestyle through mass media; progressive process of secularization of society resulting in moral breakdown and increase of aggression, as well as brutalization of life; after: M. Orłowska, B. Sobczyk, Wspótczesny obraz rodziny - hit czy kit?, [in:] Rodzicielstwo w sytuacji dezorganizacji rodziny i możliwości wspomagania rodziców, ed. J. Brągiel, B. Górnicka, Wydawnictwo Uniwersytetu Opolskiego, Opole 2014, pp. 17-26. 
raising self-esteem and security (mutual protection), ensuring biological continuity of generations (the birth of offspring), as well as ensuring the transmission of cultural and normative tradition and creating close autonomous community (recreational and social environment). ${ }^{6}$ "Family, as the closest group of people, can significantly influence the rehabilitation process". ${ }^{7}$ It gives meaning to life. It allows for a proper functioning thanks to maximum and purposeful use of one's capabilities 8 , resulting in the enhancement of the development of an adult on an individual and social level by permanent acquisition of new experiences and skills. ${ }^{9}$

\section{Parenting as a factor enhancing human development}

Parenting means being a parent, father or mother. ${ }^{10}$ This word is associated with the verb "give birth", which means "give origin to something or give birth to offspring". ${ }^{11}$ Parenting, due to the durability and type of relationship between adults and a child, can take different forms. Genetic and biological parenthood is its original natural face. The establishment of a close emotional bond between the child and their parents, and gradual raising them to perform

${ }^{6}$ S. Kotowski, Przewodnik po problematyce osób niewidomych $i$ stabowidzacych, Foundation of the Polish Blind and Visually Impaired "Trakt"; State Fund for Rehabilitation of Disabled People, Warsaw 2008, p. 164.

7 R. Ossowski, Ksztattowanie obrazu własnej sytuacji i siebie u inwalidów wzroku w procesie rehabilitacji, Wydawnictwo Uczelniane WSP Bydgoszcz, Bydgoszcz 1982, p. 30 .

${ }^{8}$ K. Obuchowski, Psychologia dążeń ludzkich, Wydawnictwo Naukowe PWN, Warsaw 1966, p. 232.

${ }^{9}$ A. Kwak, Rozwojowy charakter rodzicielstwa - podstawowe zakresy zmian, [in:] Rodzicielstwo w różnych fazach rozwoju rodziny, ed. J. Brągiel, B. Górnicka, Wydawnictwo Uniwersytetu Opolskiego, Opole 2017, pp. 37-39.

10 Uniwersalny Stownik Jezzyka Polskiego, ed. S. Dubisz, vol. 3, Wydawnictwo Naukowe PWN, Warsaw 2003, p. 961.

11 K. Długosz-Kurczatowa, Wielki Stownik Etymologiczno-Historyczny Jezyka Polskiego, Wydawnictwo Naukowe PWN, Warsaw 2008, p. 550. 
roles is social parenthood, while taking care of a young person as a result of the ritual is called ceremonial parenthood. ${ }^{12}$

Parenthood involves a number of interactions that contribute to the implementation of parental role. The first dimension of this role is care, serving to meet both basic human needs (shelter, food, cleanliness etc.) and higher ones, which can be described as a feeling of emotional comfort, guaranteeing mutual love and safety. Another task of parental role is control, which means educational commitment consisting in setting boundaries. The last area of parental involvement is ensuring development, and therefore conditions and activities supporting the natural resources (talents and predispositions) of the offspring. ${ }^{13}$

The performance of parental role requires a potential that includes non-material and material means (finances, social resources). Non-material means include primarily a mature personality ${ }^{14}$, psychological and social competences, knowledge and motivation to make commitments for the child.

A person with a mature personality, according to Gordon W. Allport, is characterised by three most important characteristics: an extended self-image, an objective attitude towards themselves and a crystallized world view.

12 D. Jabłoński, D. Ostasz, Zarys wiedzy o rodzinie, matżeństwie, kohabitacji i konkubinacie. Perspektywa antropologii kulturowej i ogólnej, Wydawnictwo Adiaphora, Olsztyn 2001, pp. 111-120.

${ }^{13}$ A. Kwak, Rodzicielstwo - przejaw społecznej współzależności, [in:] Rodzicielstwo między domem, prawem, stużbami społecznymi, ed. A. Kwak, Wydawnictwo Akademii Pedagogiki Specjalnej, Warsaw 2008, pp. 24-25.

14 Personality, according to L.A. Pervin "is a complex whole of thoughts, emotions and behaviours, giving direction and pattern (coherence) to human life. Similarly to the body, personality consists of both structures and processes, and reflects the activity of both nature (genes) and the environment. The concept of personality also includes the temporal aspect of human functioning, because the personality contains memories of the past, mental representations of the present, as well as ideas and expectations about the future". Personality is responsible for the coherence of human behaviour, feelings and thoughts; after: L.A. Pervin, Psychologia osobowości, Gdańskie Wydawnictwo Psychologiczne, Gdańsk 2002, p. 416. 
An extended self-image means limiting selfish attitudes, authentic interest in other people and their good (having friends, children, interest in the problem of the surrounding), internalization of moral patterns and behaviours which comply with them. An objective attitude towards oneself is the ability to take self-criticism, a self-distance, while having a crystallized world view is equivalent to a professed hierarchy of values. ${ }^{15}$ Maturity to undertake parental duties is manifested in the ability to establish and maintain intimate relationships and responsibility for another person. ${ }^{16}$

Parental competence is different for mother and father. The father's role is to be an authority and a giver of life. This primary function implies the father's authority towards the child, as well as his responsibility for them. The father provides care, gives emotional support and helps the offspring achieve full autonomy and dignity, and thus serves to bring up a person who is free, responsible, self-confident and able to decide about themselves. The father's role is to create an atmosphere of confidence, security and openness to the world. He should set an example for his children. ${ }^{17}$ Entering the role of mother begins from the moment of conceiving a child, through the period of pregnancy, childbirth and feeding. Culturally, motherhood is associated with the expression of feelings and the creation of an emotional atmosphere in the family, satisfying various needs, and introducing offspring into the wider circle of family community and tradition. Customarily, the mother's role is to organise and run a household, to provide care and upbringing, to give inspiration for family life and to act as a social and sexual partner for her husband. Motherhood of modern times is the need to simul-

15 G.W. Allport, Personalisty: a psychological interpretation, H. Holt, New York 1937, pp. 217-223.

16 E. Gurba, Wczesna dorostość, [in:] Psychologia rozwoju człowieka. Charakterystyka okresów życia człowieka, ed. B. Harwas-Napierała, J. Trempała, Wydawnictwo Naukowe PWN, Warsaw 2008, p. 219.

17 R. Fernández, Rola ojca, "Communio. Międzynarodowy Przegląd Teologiczny" 1999, no. 2, p. 111, 115, 121-122. 
taneously perform parental, marital and professional roles with conflicting priorities. ${ }^{18}$

Acquiring and possessing knowledge, as a non-material factor supporting the fulfilment of parental roles, is a sign of active parenthood. Thanks to the knowledge, the parent recognizes developmental norms, needs, as well as properly develops relationships with the child. Knowledge helps in making right decisions at various stages of parenting. Acquiring knowledge is preceded by an internal motivation to take up parental tasks, which is caused by the characteristics of the mental development of a person in early adulthood ${ }^{19}$, personal needs and cultural pressure associated with the need to have own reproductive family

Parenting is a process in the life of an adult that enhances their individual development. According to Maria Tyszkowa, "Family, and respective fulfilment of social family roles and participation in a specific system of relationships and personal interactions, implying a specific activity of the individual, becomes a source of experience. This experience, after being developed in the mental apparatus of the individual, is incorporated into the psychological subsystem, initiating its transformation and gradually leading to developmental changes in the entire mental system of the individual" ${ }^{20}$ There-

18 A. Kwak, Rodzicielstwo - przejaw społecznej wspótzależności, [in:] Rodzicielstwo między domem, prawem, stużbami społecznymi, ed. A. Kwak, Wydawnictwo Akademii Pedagogiki Specjalnej, Warsaw 2008, p. 23; M. Matuszewska, Funkcjonowanie w rolach rodzicielskich jako źródło rozwoju młodych dorostych, [in:] Rodzina a rozwój człowieka dorosłego, ed. B. Harwas-Napierała, Wydawnictwo Naukowe Uniwersytetu im. Adama Mickiewicza, Poznań 2003, p. 34.

19 Adulthood is a phase of human life that follows rapid developmental changes of a biological and social nature. It is characterised by the ability to procreate and responsibly undertake new social roles related to starting own family, giving birth to children and raising them, conducting professional activity and autonomous management of own life. The period of early adulthood is between 23-35 years of age; after: E. Gurba, Wczesna dorosłość, [in:] Psychologia rozwoju człowieka. Charakterystyka okresów życia człowieka, ed. B. Harwas-Napierała, J. Trempała, Wydawnictwo Naukowe PWN, Warsaw 2008, p. 203.

${ }^{20}$ M. Tyszkowa, Jednostka a rodzina: interakcje, stosunki, rozwój, [in:] Psychologia rozwoju człowieka. Zagadnienia ogólne, eds. M. Przetacznik-Gierowska, M. Tyszkowa, Wydawnictwo Naukowe PWN, Warsaw 2009, p. 136. 
fore, family is not only the smallest social group in the sociological perspective and the educational care environment for the child, guaranteeing their development through interaction ${ }^{21}$, but it constitutes the "developmental context (...) of an adolescent and adult22. Development occurs through experience and positive multidirectional relationships of the person with the environment. Unfavourable, pathological family experiences can, by analogy, disturb the psychological and social development of the person. At the same time, developmental changes taking place in family members and their activity affect changes in the functioning of the family as a whole, transforming interpersonal relationships and the operation of the entire system..$^{23}$

Fulfilling parental role is an entry into the development process. The fundamental task of this process is to make a lasting contribution to social life and leave a heritage in the form of offspring. Parenting gives this opportunity by favouring the achievement of marital satisfaction, becoming one of the conditions for a peaceful ageing process ${ }^{24}$ and allowing for permanent learning. ${ }^{25}$ An adult, thanks

${ }^{21}$ According to U. Bronfenbrenner "Primary developmental context is a context in which a child can observe and adopt patterns, increasingly complex activities in cooperation or under the direct guidance of people who have knowledge and skills not yet mastered by a child and with whom the child has a positive emotional relationships"; after: U. Bronfenbrenner, The ecology of human development: Experiments by nature and design, Harvard University Press, Cambridge 1979, p. 845.

${ }^{22}$ M. Tyszkowa, Jednostka a rodzina: interakcje, stosunki, rozwój, [in:] Psychologia rozwoju człowieka. Zagadnienia ogólne, eds. M. Przetacznik-Gierowska, M. Tyszkowa, Wydawnictwo Naukowe PWN, Warsaw 2009, p. 126.

${ }^{23}$ M. Tyszkowa, Jednostka a rodzina: interakcje, stosunki, rozwój, [in:] Psychologia rozwoju człowieka. Zagadnienia ogólne, eds. M. Przetacznik-Gierowska, M. Tyszkowa, Wydawnictwo Naukowe PWN, Warsaw 2009, pp. 136-139; B. Harwas-Napierała, Zmiany w funkcjonowaniu rodziny i ich konsekwencje dla rozwoju rodziców, [in:] Rodzina a rozwój człowieka dorosłego, ed. B. Harwas-Napierała, Wydawnictwo Naukowe Uniwersytetu im. Adama Mickiewicza, Poznań 2003, p. 11.

${ }^{24}$ Engagement in parenthood is a solution to the developmental crisis of adulthood, which, as one of many, is described by Erik H. Erikson (1968) in his generativity theory. According to E.H. Erikson (1968), parenting is the most important activity of adulthood, which determines human creativity in other areas of life; after: 
to fulfilling parental tasks, is constantly expanding their experience, knowledge and skills, which allows them to more fully use their own biological and psychosocial potential. ${ }^{26}$ Engaged parenthood results in changes especially in the functional (new duties and skills), personality and emotional (new quality in interpersonal relationships) and cognitive (new knowledge) areas. ${ }^{27}$

Do people with disabilities have a chance to develop through parenting? The desire to have own family and to be a parent is a common desire that is equivalent to various anxieties. One of them includes social barriers in the form of prejudices. ${ }^{28}$ The right to achieve one's happiness through an intimate relationship with another person in Polish society is associated with the stereotypical

B. Harwas-Napierała, Zmiany w funkcjonowaniu rodziny $i$ ich konsekwencje dla rozwoju rodziców, [in:] Rodzina a rozwój człowieka dorostego, ed. B. Harwas-Napierała, Wydawnictwo Naukowe Uniwersytetu im. Adama Mickiewicza, Poznań 2003, p. 20.

${ }^{25}$ Fulfilling developmental tasks in human life is inseparably associated with learning. This relationship was described by Robert J. Havighurst (1981), claiming that psychological development is accomplished by changing the activity in which a human is involved in specific developmental periods; after: L. Bakiera, Zaangażowane rodzicielstwo a autokreacyjny aspekt rozwoju dorostych, Wydawnictwo Difin S.A., Warsaw 2013, p. 106.

${ }^{26}$ The concept of psychotransgressionism described by Józef Kozielecki (1987) defines a human as a person undertaking transgressive activities, or intentional acts of causative activity. Parenting is one of such acts that proceeds "towards oneself", "towards people", "towards symbols" and "towards things"; after: L. Bakiera, Zaangażowane rodzicielstwo a autokreacyjny aspekt rozwoju dorostych, Wydawnictwo Difin S.A., Warsaw 2013, p. 115.

${ }^{27}$ M. Matuszewska, Petnienie spotecznych ról rodzinnych przez młodych dorostych i ich rozwój indywidualny, [in:] Rodzina a rozwój jednostki, ed. M. Tyszkowa, Central Program for Basic Research CPBP, Poznań 1990, p. 87; M. Matuszewska, Funkcjonowanie w rolach rodzicielskich jako źródło rozwoju młodych dorostych, [in:] Rodzina a rozwój człowieka dorosłego, ed. B. Harwas-Napierała, Wydawnictwo Naukowe Uniwersytetu im. Adama Mickiewicza, Poznań 2003, p. 31; L. Bakiera, Petnienie ról rodzicielskich a rozwój dorostych w wieku średnim, „Psychologia Rozwojowa” 2004, vol. 9, no. 2, p. 40, 45 .

${ }^{28}$ D. Kornas-Biela, Postawy społeczne wobec matżeństwa i macierzyństwa kobiet z niepetnosprawnością, [in:] Kobiecość a niepetnosprawność, ed. W. Janocha i K. Zielińska-Król, Wydawnictwo KUL, Lublin 2015, p. 19. 
image of youth, attractiveness and physical fitness. The general image of people with disabilities does not fit this stereotype, in which, in public discourse, the right to transfer life is suspended. ${ }^{29}$

\section{Psychological context of parenting of people with visual impairment}

The condition of visual perception, the co-occurrence of chronic multiple diseases, as well as the time of acquisition of disability have an impact on the mental functioning of a born blind, and partially sighted person and a person who became blind later, as well as the planned and fulfilled parental roles. ${ }^{30}$ Being a parent requires internal self-creation. It becomes an impulse to overcome the mental barrier created as a result of disability.

Blind people, because of the total loss of a possibility to receive visual sensation, experience limitations in the area of cognitive, orientation and spatial, and performance (everyday activities) capabilities. The indicated difficulties can only be overcome in part with a huge effort involved. Personality and everyday functioning of a blind person depend on the model of upbringing in a family of origin, their own activity, as well as their attitude towards the environment and its attitudes towards a disabled person. Household members who are Indifferent, have a negative attitude or are overprotective bring up a person unable to take on basic activities enabling independent life. Lack of own activeness will inhibit the development of cognitive and practical activities. Conscious isolation from the environment or its negative attitudes will result in a lack of social skills and resignation from undertaking tasks. Unfavourable experience accumulated in the course of individual life will deter-

29 S. Waszczak, Stosunek społeczeństwa do osób niepetnosprawnych, „Problemy Polityki Społecznej" 2000, no. 2, p. 96.

30 A. Bojarska, Uwarunkowania macierzyństwa kobiet niewidomych i stabowidzacych, [in:] Kobiecość a niepetnosprawność, ed. W. Janocha, K. Zielińska-Król, Wydawnictwo KUL, Lublin 2015, p. 68. 
mine the shape of adult life of a blind person and effectiveness in fulfilling parental roles. ${ }^{31}$

Partially sighted people, with limited vision, function better than blind people. At the same time, possessed perceptual resources can paradoxically be a burden when performing daily activities, because the state of visual functioning of partially sighted people is variable, which ultimately puts this group in an ambiguous situation. This is because they are not blind or fully sighted people, therefore they are less likely to accept their disability. Partially sighted people constantly confront their functional skills with the capabilities of the sighted, assessing them as limited and preventing the fulfilment of dreams and life plans. The social environment perceives this group as less competent at undertaking significant tasks, which results in the formation of an introvert attitude, lower selfesteem, as well as a tendency to isolate and resign from important life goals. ${ }^{32}$

Blind people, as a result of partial or complete loss of vision during the course of their life, experience permanent stress that hinders adaptation activities and the ability to cope with specific situations. Severe visual disability destroys the already formed personality (a sense of physical difference, destruction of the system of knowledge about oneself and relationships with the environment) and creates the need for psychological adaptation to a new situation. A blind person experiences disturbances in terms of exploration of reality, spatial orientation, loses a sense of security and many practical skills mastered during previous life. Limitation of activity

${ }^{31}$ T. Majewski, Psychologia niewidomych i niedowidzacych, Państwowe Wydawnictwo Naukowe, Warsaw 1983, pp. 70-147; S. Kotowski, Przewodnik po problematyce osób niewidomych i stabowidzacych, Foundation of the Polish Blind and Visually Impaired "Trakt"; State Fund for Rehabilitation of Disabled People, Warsaw 2008, pp. 35-49.

${ }^{32}$ T. Majewski, Psychologia niewidomych i niedowidzacych, Państwowe Wydawnictwo Naukowe, Warsaw 1983, p. 174; S. Kotowski, Przewodnik po problematyce osób niewidomych $i$ stabowidzacych, Foundation of the Polish Blind and Visually Impaired "Trakt"; State Fund for Rehabilitation of Disabled People, Warsaw 2008, pp. 35-39. 
causes apathy, helplessness and confusion. A blind man loses his position as a leader who conquers and modifies reality. A woman feels less attractive and competent in the potential role of partner and parent. If she is a wife and mother, she has to overcome the difficulties associated with running a household, caring for children and maintaining social status. A blind person is forced to temporarily resign or completely change the performed tasks (change or resignation from work). The previous contacts with the extra-familial environment are weakened, and access to various forms of cultural, educational and relaxation activities can be hindered, which has an adverse effect on the mental functioning of the person. ${ }^{33}$

Table 1. Characteristics of the mental functioning of people with visual impairment

\begin{tabular}{|l|l|l|}
\hline \multicolumn{1}{|c|}{ People born blind } & \multicolumn{1}{|c|}{ Partially sighted people } & \multicolumn{1}{|c|}{$\begin{array}{c}\text { People who became blind } \\
\text { in later period }\end{array}$} \\
\hline Limited cognitive ability & limited visual capability & $\begin{array}{l}\text { permanent stress hindering } \\
\text { adaptation }\end{array}$ \\
\hline $\begin{array}{l}\text { Limited orientation and spa- } \\
\text { tial ability }\end{array}$ & $\begin{array}{l}\text { Limited executive possibilities } \\
\text { (life activities) }\end{array}$ & $\begin{array}{l}\text { loss of male position / deval- } \\
\text { uation of female role }\end{array}$ \\
\hline $\begin{array}{l}\text { Limited executive possibilities } \\
\text { (life activities) }\end{array}$ & $\begin{array}{l}\text { confrontation of own visual ca- } \\
\text { pabilities with those of the } \\
\text { sighted }\end{array}$ & $\begin{array}{l}\text { new difficulties and limita- } \\
\text { tions in everyday life / loss of } \\
\text { practical skills }\end{array}$ \\
\hline $\begin{array}{l}\text { Motivation to undertake activ- } \\
\text { ities and integrate with the en- } \\
\text { vironment required }\end{array}$ & $\begin{array}{l}\text { introverted attitude and } \\
\text { lower self-esteem }\end{array}$ & $\begin{array}{l}\text { self-esteem crisis and loss of } \\
\text { sense of security }\end{array}$ \\
\hline $\begin{array}{l}\text { Training in cognitive and } \\
\text { practical skills required }\end{array}$ & $\begin{array}{l}\text { tendency to isolation from the } \\
\text { environment }\end{array}$ & $\begin{array}{l}\text { personality disintegration / } \\
\text { apathy and feeling of being lost }\end{array}$ \\
\hline
\end{tabular}

Source: own work.

The psychological situation of parents who were born blind, are partially blind and lost their sight in a later period depends not only on the health condition, but also on the partnership configuration in

33 T. Majewski, Psychologia niewidomych i niedowidzących, Państwowe Wydawnictwo Naukowe, Warsaw 1983, pp. 175-189. 
the relationship, which can take the following forms: both partners with visual impairment, a blind or partially sighted partner or a partner who lost their sight in a later period. Single parenthood (usually motherhood) of people with visual impairment is not uncommon. Most often relationships are formed by blind men with sighted women. Pairs of two blind people are also full of harmony. Blind women starting families with sighted men are most rare. ${ }^{34}$ In all of the mentioned cases, the condition of visual functioning and the level of general rehabilitation affect the way of fulfilling parental roles.

Table 2. Partnership configurations in relationships of people with visual impairment

\begin{tabular}{|c|c|c|}
\hline Partnership configurations & Positive characteristics & Negative characteristics \\
\hline $\begin{array}{l}\text { Sighted woman / man } \\
\text { with visual impairment }\end{array}$ & $\begin{array}{l}\text { - professional and financial } \\
\text { independence of the man } \\
\text { - harmony of life despite diffi- } \\
\text { culties / connection and un- } \\
\text { derstanding }\end{array}$ & $\begin{array}{l}\text { - conflict and misunderstanding } \\
\text { of the man by the family of the } \\
\text { woman } \\
\text { - making first intimate contacts } \\
\text { is difficult }\end{array}$ \\
\hline $\begin{array}{l}\text { Both partners with visual } \\
\text { impairment }\end{array}$ & $\begin{array}{l}\text { - honesty / mutual understand- } \\
\text { ing of needs and difficulties / } \\
\text { partnership } \\
\text { - good preparation for life is } \\
\text { necessary } \\
\text { - activity / financial independ- } \\
\text { ence }\end{array}$ & $\begin{array}{l}\text { - lack of mutual efficient help } \\
\text { - childcare is difficult } \\
\text { - contact with the environment } \\
\text { is difficult }\end{array}$ \\
\hline $\begin{array}{l}\text { Sighted man / woman } \\
\text { with visual impairment }\end{array}$ & $\begin{array}{l}\text { - characteristics of women: } \\
\text { physical attractiveness, inde- } \\
\text { pendence in life, integration } \\
\text { with the environment }\end{array}$ & $\begin{array}{l}\text { - the necessity to meet various } \\
\text { household responsibilities / } \\
\text { resourcefulness in life, spatial } \\
\text { orientation, efficient movement }\end{array}$ \\
\hline Life alone & $\begin{array}{l}\text { - desire for a close lasting rela- } \\
\text { tionship } \\
\text { - desire to start a family }\end{array}$ & $\begin{array}{l}\text { - lower physical attractiveness / } \\
\text { worse professional perspec- } \\
\text { tive, anxiety, loneliness }\end{array}$ \\
\hline
\end{tabular}

Source: own work.

34 J. Kawka, Warunki wychowawcze dzieci w rodzinach inwalidów wzroku, Wydawnictwo UMCS, Lublin 1996, pp. 26-27; A. Duracz-Walczakowa, Wybrane problemy życia rodzinnego niewidomych, "Studia Socjologiczne” 1966, no. 1, p. 213. 
Desirable characteristics of a woman as a partner and mother are: attractiveness, independence, resourcefulness, diligence, self-esteem and no additional disability. A man with visual impairment who wants to start a family should be professionally and financially resourceful, able to move independently around the world, socially integrated and positively assessing himself.

\section{Functional context of parenting of people with visual impairment}

Parents with visual impairment also experience developmental dynamics in the sphere of activity (new responsibilities and skills). Achieving success, however, requires overcoming existing functional obstacles. Difficulties of blind people's spouses in taking care of their offspring and running a household are greater than in marriages where one person is blind or partially sighted, or both have visual impairment, but to varying degrees.

Regardless of the encountered difficulties, according to the results of J. Kawka' study, "Families of people with visual impairment correctly fulfilled the tasks arising from the basic functions," and "The educational conditions of children in these families, (...), did not differ significantly from the accepted social standards". 35

The basic care-providing and upbringing tasks include the ability to organise the care of children of different ages at home and to cooperate with preschool, school, non-school educational and upbringing institutions as well as healthcare facilities.

35 J. Kawka, Warunki wychowawcze dzieci w rodzinach inwalidów wzroku, Wydawnictwo UMCS, Lublin 1996, p. 165; J. Kawka (1996) conducted comparative studies in a group of 60 families of people with visual impairment and 60 families of ablebodied people analysing the socialization values of the following basic functions: material and economic, protective and securing, emotional and expressive, recreational and social, as well as cultural ones, which had an impact on shaping the educational conditions of children in the families of people with visual impairment. 
Table 3. Developmental dynamism and functional barriers of parenthood of people with visual impairment

\begin{tabular}{|c|c|c|}
\hline Development spheres & $\begin{array}{c}\text { Developmental dynamism } \\
\text { stages }\end{array}$ & Person with visual impairment \\
\hline Functional sphere & $\begin{array}{l}\text { undertaking new forms of } \\
\text { activity as part of family roles / } \\
\text { low level of organization }\end{array}$ & $\begin{array}{l}\text { - need for functional adapta- } \\
\text { tions in all spheres of life }\end{array}$ \\
\hline \multirow{4}{*}{$\begin{array}{l}\text { Personality } \\
\text { And adaptation sphere }\end{array}$} & $\begin{array}{l}\text { ANTICIPTION (thinking about } \\
\text { parenthood) / mental growing } \\
\text { to be a parent }\end{array}$ & $\begin{array}{l}\text { - anxiety / difficult duties / } \\
\text { inheritance of disability } \\
\text { - risk of deterioration of health } \\
\text { - criticism of the environment }\end{array}$ \\
\hline & $\begin{array}{l}\text { HONEYMOON (shortly after } \\
\text { childbirth) / learning the role of } \\
\text { a parent / building connections } \\
\text { with the child }\end{array}$ & $\begin{array}{l}\text { - new life goals / higher self- } \\
\text { esteem } \\
\text { - building relationships with } \\
\text { the child / alternative ways } \\
\text { - functional difficulties associat- } \\
\text { ed with childcare }\end{array}$ \\
\hline & $\begin{array}{l}\text { PLATEAU (childhood, adoles- } \\
\text { cence) / constant adaptation of } \\
\text { attitudes, knowledge, experi- } \\
\text { ence }\end{array}$ & $\begin{array}{l}\text { - functional adjustment of eve- } \\
\text { ryday activities } \\
\text { - control of school progress is } \\
\text { difficult } \\
\text { - need to build good / difficult } \\
\text { relationships with the envi- } \\
\text { ronment } \\
\text { - sometimes living in adverse } \\
\text { material conditions }\end{array}$ \\
\hline & $\begin{array}{l}\text { RELEASE / end of active parent } \\
\text { role }\end{array}$ & •loneliness \\
\hline Cognitive sphere & $\begin{array}{l}\text { acquiring new knowledge / } \\
\text { creative thinking / willingness } \\
\text { to change }\end{array}$ & $\begin{array}{l}\text { - difficult / lack of education } \\
\text { and professional information } \\
\text { services for parents }\end{array}$ \\
\hline
\end{tabular}

Source: own work; Parenting phases are presented on the basis of the Group for the Advancement of Psychiatry (GAP), after: M. Matuszewska, Funkcjonowanie w rolach rodzicielskich jako źródło rozwoju młodych dorostych, [in:] Rodzina a rozwój człowieka dorosłego, ed. B. Harwas-Napierała, Wydawnictwo Naukowe Uniwersytetu im. Adama Mickiewicza, Poznań 2003, p. 31.

The challenge of infancy includes care of a small child, ensuring their safety and harmonious development. Parents with visual impairment acquire first nursing skills, benefiting from the assistance 
of friendly sighted people (immediate family, friends with children) or the advice of qualified medical staff in hospital and outpatient settings right after the birth of the child.

"My family, a friend who had a few months older child and a midwife from the clinic who came for a home visit helped me a lot". ${ }^{36}$

The organization of parental duties at home requires preparation of a place to sleep, play and nursing activities. The latter cause some difficulties, especially for inexperienced parents, and they include: feeding, changing clothes of the baby, changing a diaper, bathing, cutting nails, checking the quality of the child's skin, and in case of illness: measuring temperature, cleaning the nose or dosing medicines. The main channel of contact with the child, in the case of blind parents, is touch (carrying in hands, embracing, caressing, hugging), sound stimulation (voice of parents) and hearing enabling the control of child's behaviour. Preparation of a place for nursing requires functional solutions. Parents with visual impairment will perform all necessary activities if the necessary objects are within the reach of their hands, left in good order, and if they have the opportunity to learn about their proper and safe performance. A wide range of items for nursing available on the market allows for the choice of those that will help in relatively efficient and safe performance of nursing tasks.

"It is important for us to have those activities shown or very precisely described by someone. It should also be remembered that we must learn a good organisation in the place where these activities are performed, the child must lie safely $(\ldots)^{\prime \prime} \cdot 37$

${ }^{36}$ Author of the statement Dominika Buchalska; after: E. Fraszka, E. Oleksiak, Być mama, być Tatą. Poradnik dla niewidomych rodziców, Polish Association of the Blind, Warsaw 2017, p. 19.

37 Author of the statement Dominika Buchalska; after: E. Fraszka, E. Oleksiak, Być mama, być Tata. Poradnik dla niewidomych rodziców, Polish Association of the Blind, Warsaw 2017, pp. 21-22. 
The period of early childhood and the time of beginning of school duties are turning points that impose on parents and children new challenges that go beyond the scope of care and nursing duties. The child demands emotional contact through mutual communication and play.

They acquire new intellectual and motor skills. The living environment expands beyond the boundaries of the immediate environment. Progressive development, high mobility of the child, ability to move efficiently combined with curiosity about the world and unawareness of parental restrictions pose an organizational, as well as orientation and cognitive challenge for parents.

The immediate surroundings must be safe.

"(...) The most important thing is to create a safe environment. It is necessary to secure electrical sockets, hide (...) cables, (...) hide sharp tools (knives, scissors). (...) Do not leave cups with hot drinks (...) near the child. (...) If the environment is secured, then the child (...) can move freely around the house (...). It is necessary to teach children safe behavious (...). ${ }^{38}$

Common walks require the use of solutions that allow for locating the child and controlling them during the play. A lot of help is provided by safely organized recreation areas and the help of sighted friends who observe the activity of the child. Support of sighted people can also be useful in situations where the preferred activity exceeds the capabilities and skills of parents. This happens when the time comes to learn how to ride a bike, roller skate, ride a scooter or train swimming. Properly selected equipment along with the necessary security and the help of a volunteer or professional instructor supports disabled parents.

„Walking with the first child was a difficult challenge. (...) Leading reins proved to be a very good solution (...). When the child was a bit older and ran

${ }^{38}$ Author of the statement Dominika Buchalska; after: E. Fraszka, E. Oleksiak, Być mama, być Tata. Poradnik dla niewidomych rodziców, Polish Association of the Blind, Warsaw 2017, pp. 43-44. 
around the playground alone, the bell tied to the clothes worked very well (...). When the child was older (...) they were coming if they needed help". ${ }^{39}$

Starting preschool and school education requires more frequent contact with the staff of these institutions and parents of other students. Difficulties in this integration deprive parents with disabilities of information about the school situation of their own child. Therefore, a friendly understanding of the teaching environment for the restrictions of disabled parents and assistance in the area of integration and adaptation are necessary. The period of education entails a number of functional dilemmas. The first is to prepare the student's workshop and check the state of preparation for school activities. Children of disabled parents learn responsibility and discipline in this respect.

“(...) School age is the time when we teach a child responsibility for their behaviour, so also packing a backpack and preparing for classes must be gradually passed into the hands of the child". ${ }^{40}$

Performing artistic work and learning colours together, reading picture books, writing exercises and supporting the child during homework are not easy tasks.

Full control of the quality, correctness and completeness of the performed work by a blind parent is impossible. In this regard, cooperation with the teacher and the help of the sighted person at the initial stage of child's education are necessary. Performing artistic work at home will become easier thanks to the preparation of simple aids introducing the names of colours and ready-made templates to help draw shapes. The works may also be of a spatial nature requiring cutting, wrapping, sticking or gluing ready elements.

${ }^{39}$ Author of the statement Dominika Buchalska; after: E. Fraszka, E. Oleksiak, Być mama, być Tatą. Poradnik dla niewidomych rodziców, Polish Association of the Blind, Warsaw 2017, p. 42.

40 Author of the statement Dominika Buchalska; after: E. Fraszka, E. Oleksiak, Być mama, być Tatą. Poradnik dla niewidomych rodziców, Polish Association of the Blind, Warsaw 2017, p. 39. 
Art education is conducted during preschool and school classes. If the family there are siblings, children learn many skills from each other. Reading picture books together requires the addition of a black print text with a Braille version (print on a transparent tape stuck to the pages of the book). Parents are also supported by sound books, audiobooks and the help of sighted people. Initial learning of letters, numbers, writing, reading and counting can be supported by the use of spatial models (letters and numbers, magnets), educational games available for the blind ("Ludo", "Nine men's morris"), books for graphomotor exercises. The correctness of the text read by the child is controlled by providing the alphabet book with a Braille text.

"We decided that our child would not attend kindergarten, so we tried to teach them as much as possible" ${ }^{41}$

The development of social contacts is an essential element of proper socialization. The children of parents with visual impairment, entering the world of peer contacts, must face the need to explain the consequences of their parents' disability. They are also forced to individually understand and accept these consequences. Some parents, feeling too little trust from their surroundings, try to constantly prove that they are competent guardians. The quality of social perception of the functioning of a special family will be a condition for the adaptation of this family in the environment.

“(...) Some [parents, author's note], living under great social pressure, believe that they should feel three times more responsible for the child than sighted parents, because they belong to a high risk group (...)". ${ }^{42}$

41 Author of the statement Anna Ponichtyra; after: E. Fraszka, E. Oleksiak, Być mama, być Tatą. Poradnik dla niezidomych rodziców, Polish Association of the Blind, Warsaw 2017, p. 51.

42 Author of the statement Monika Marczuk-Engelsma; after: E. Fraszka, E. Oleksiak, Być mama, być Tatą. Poradnik dla niewidomych rodziców, Polish Association of the Blind, Warsaw 2017, p. 59. 
Child care of parents with visual impairment is slightly different from care and upbringing activities undertaken by sighted people. The main difference consists in the functional adaptation of everyday activities and the need to use, in some situations, the assistance of sighted people. Raising a child in the situation of the mentioned disability is an undoubted developmental impulse for parents, because "(...) Along with (...) the acquisition of new skills by a child, parents also learn new things". 43

\section{Educational context of parenting of people with visual impairment}

Performing parental tasks in a mature way requires skills in self-esteem of own mental and moral attitudes, their improvement and gradual acquisition of practical knowledge, skills and experience. People can and should prepare for the role of a parent in a planned way.

Parents and the environment of a family of origin should be the first teachers of femininity and masculinity. The second place of education and upbringing is the school and a substantively prepared teacher who is able to tactfully talk to young people about their needs, doubts and hopes. Since 2009, the subject "Preparation for family life" has been introduced in the framework of school curricula". ${ }^{44}$ According to the data of the Educational Research Insti-

43 Author of the statement Dominika Buchalska; after: E. Fraszka, E. Oleksiak, Być mama, być Tata. Poradnik dla niewidomych rodziców, Polish Association of the Blind, Warsaw 2017, p. 34.

44 Based on the: Regulation of the Minister of National Education of 12 August 1999 on the method of school teaching and the scope of content regarding knowledge on the sexual life of an individual, principles of conscious and responsible parenthood, the value of the family, life in the prenatal phase, as well as on methods and measures of conscious procreation contained in the general education program (Journal of Laws 1999, No. 67, item 756) and the Regulation of the Minister of National Education of 28 March 2017 on the outline timetables in public schools (Journal of Laws 2017, item 703) the subject "Preparation for family life" (as op- 
tute, $87 \%$ of lower secondary high school students and $48 \%$ of upper secondary school students participated in these activities. According to the respondents, the significant drop in attendance between both types of schools was caused by the inadequate location of "Preparation for family life" in the teaching schedule. Other reasons for this lack of interest are: an uninteresting program and a teacher who runs the classes in the incorrect way. Students attending "Preparation for family life" rated it very positively $(62 \%$ of lower secondary school students; $71 \%$ of upper secondary students), indicating the presence of useful content consistent with the professed system of values. However, the existing formula for the optionality of these lessons was confirmed, by the fact that students who did not attend classes had slightly better results in the test checking basic knowledge of human sexuality. 45

Blind and partially sighted youth is often educated in boarding school and education centres, so the obligation to solve problems in

posed to the "Sex education" classes) was introduced, covering knowledge about the sexual life of an individual, principles of conscious and responsible parenthood, the value of the family, life in the prenatal phase, as well as on methods and measures of conscious procreation. In public schools, in the school curriculum, "Preparation for family life" classes comprise, in each school year, 14 hours for students of individual grades, including 5 hours with the division into groups of girls and boys. Classes are organized within grades or inter-grade groups of no more than 28 students. The subject is conducted in grades IV-VIII of primary school and in secondary schools including: vocational school of the first grade, grades I-III of general secondary school and grades I-III of technical secondary school. A minor student is not obliged to take part in the classes if their parents (legal guardians) notify the headmaster in writing of their resignation from the participation in the classes. An adult student does not take part in the classes if they notify the headmaster in writing of their resignation. "Preparation for family life" lessons are not subject to assessment and do not affect the promotion of the student to a higher form or the graduation of the student.

${ }^{45}$ K. Bulkowski, M. Federowicz, W. Grajkowski, R. Kaczan, K. Maliszewska, D. Marszał, M. Męziński, U. Poziomek, P. Rycielski, D. Walczak, A. Wichrowski, Opinie i oczekiwania młodych dorostych (osiemnastolatków) oraz rodziców dzieci w wieku szkolnym wobec edukacji dotyczacej rozwoju psychoseksualnego i seksualności. Raport $z$ badania, Educational Research Institute, Warsaw 2015, p. 39-45. 
the field of "sex education" falls on educators, teachers and school psychologists who often do not have proper content-related and methodological preparation, and do not have teaching materials and visual means adapted to the needs of people with visual impairment adjusted to their different perceptual needs. ${ }^{46}$ If the daily life environment is a family home because a teenager attends school near their place of residence, conversations about adolescencerelated topics are still not easy for many parents. ${ }^{47}$ In some families, a blind or partially sighted teenager will not get the right support, and parents do not set a good example. People with visual impairment are quite often treated as asexual, permanently immature, provided with excessive care, having no intimate life needs. Knowledge gathered incidentally from uncertain sources places a person with visual impairment in a situation of permanent and infantile misinformation, which condemns them to fleeting relationships that may end with premature sexual initiation and unplanned parenthood. 48

The curriculum of preparation for family life should be adapted to the needs of people with visual impairment not only in view of the content correlated with the age of listeners, but also related to the effects of disability, which affects the emerging difficulties in creating intimate partnerships of adolescents with visual impairment. These difficulties concern: barriers to establishing contacts with peers (no opportunity to enter into a relationship, time spent

${ }^{46} \mathrm{M}$. Zaorska drew attention to the important ethical dimension of the behaviour, attitudes and activities of specialists working in the field of sex education of people with disabilities: M. Zaorska, Etyka a problematyka seksualności osób z poważnymi, głębokimi niepetnosprawnościami, „Niepełnosprawność i Rehabilitacja” 2018, no. 1, pp. 46-52.

${ }^{47}$ K. Czerwińska, I. Kucharczyk, Tyflopsychologia, Wydawnictwo Naukowe PWN S.A., Warsaw 2019, p. 127.

48 I. Fornalik, Edukacja seksualna osób niepetnosprawnych. Notatki na marginesach ministerialnych rozporządzeń, „Kwartalnik Pedagogiczny” 2010, no. 2, p. 106; G. Kapperman, T. Brown-Ogilvie, J. Yesaitis, A. Peskin, Prevention of sexual assault against children who are visually impaired, "Division on Visual Impairments Quarterly" 2014, no. 59(2), p. 33 . 
mainly alone or with family, close relationship with parents), negative reactions of the environment (a disabled person is perceived as less attractive as a potential partner) and emotional problems of people with visual impairment (loneliness, depression). ${ }^{49}$

Therefore, the primary needs associated with the curriculum of preparation for family life, should include personal and social functional aspects. The first of them comprises skills in the area of performing everyday activities, the purpose of which is to ensure personal independence. The main scope of everyday activities includes: self-care skills (preparing meals, cleaning, washing, ironing), professional activities (vocational skills, professional work), specific activities (nursing infants and young children, care-providing and upbringing activities in the case of older children).

The second important group are social skills, which include: effective spatial orientation and independent movement, skills in social interaction and non-verbal communication to facilitate functioning in social situations, ability to spend free time favouring the establishment of advantageous social relationships. The third scope is the development of individual mental skills serving for: building self-esteem, developing leadership competences (self-confidence) correlated with predispositions to take up employment, and developing the ability to create one's own image (improving physical attractiveness by choosing the right clothing, hairstyle, make-up, knowledge of individual values and defects in the physical appearance). The fourth attribute of full preparation for life in the family and society is knowledge and access to the latest technical solutions that facilitate functioning. 50

Another pillar of the curriculum of preparation for family life is knowledge about the physical aspects of human sexuality. A person with visual impairment, should obtain information about the ana-

${ }^{49}$ K. Czerwińska, I. Kucharczyk, Tyflopsychologia, Wydawnictwo Naukowe PWN S.A., Warsaw 2019, p. 124.

${ }^{50}$ G. Kapperman, K. Page, S. Kelly, Finding the One: Human mate selection applied to persons who are visually impaired, "Division on Visual Impairments Quarterly" 2014, no. 59(2), pp. 38-44. 
tomical and physiological attributes characteristic for a woman and a man, the characteristics of the intimate life of mature people, conscious fatherhood and motherhood (natural methods of regulating fertility, advantages and side effects of contraception) in a manner adapted to their individual perceptive abilities. The subject of sexual intercourse and procreation should refer to the aspects of the consequences of inheritance of some visual disorders ${ }^{51}$, the impact of multiple disability on the health of future parents and planned offspring, as well as indicate preventive solutions for the incidence of sexually transmitted diseases. ${ }^{52}$ Blind and partially sighted people

${ }^{51}$ Genetically determined visual system diseases constitute a significant group of diseases. For this reason, a separate sub-speciality, ophthalmic genetics, has been created within clinical genetics. The occurring genetic disorders of the eye include: tapetoretinal degeneration (retinitis pigmentosa), age-related macular degeneration, glaucoma, cataract in the course of myotonic dystrophy, aniridia (congenital absence of the iris), skin and ocular albinism, colour blindness, juvenile retinal detachment, corneal dystrophies, cone-rod dystrophies, retinoblastoma, numerous metabolic diseases, Axenfeld syndrome, Marfan syndrome, Stickler syndrome, Kjer's optic atrophy, Stargardt disease (juvenile macular degeneration), Usher syndrome (dystrophia retinae dysacusis syndrome), Leber congenital amaurosis, Louis-Bar syndrome, Kearns-Sayre syndrome. Every person (family) with suspected or diagnosed genetic eye disease should have a possibility to obtain genetic advice about medical and genetic aspects of the disease. Advice may be provided by clinical genetics specialists and ophthalmologists; after: A. Wawrocka, M. Krawczyński, Genetyka w okulistyce, [in:] Okulistyka, ed. A. Grzybowski, Edra Urban \& Partner, Wrocław 2018, pp. 305-314.

52 S.M. Kelly, G. Kapperman, Sexual activity of young adults who are visually impaired and the need for effective sex education, AFB “Journal of Visual Impairment \& Blindness" 2012, no. 106, pp. 519-526; S.M. Kelly, G. Kapperman (2012), researchers from Illinois State University and Northern Illinois University (USA) conducted a comparative study between a group of 9,850 people with visual impairment (33\% of blind people; $67 \%$ of partially sighted people) and a group of 10,904 able-bodied people aged 19-23. The aim of the study was to measure and compare sexual behaviour within both study groups. The conclusions of the conducted analysis were as follows: 1) Sexual activity of people with visual impairment was similar to the activity of able-bodied respondents (the sample of respondents with visual impairment was slightly older than the sample of able-bodied people); 2) Blind and partially sighted people started active sex life from two to three years later than healthy 
should also be aware that as disabled people they are more often exposed to acts of sexual aggression (paedophilia, sexual harassment). Education in the field of preparation for family life also serves to raise awareness, vigilance and safety of people with disabilities in the face of these threats. ${ }^{53}$

The basis for establishing and maintaining a lasting close intimate relationship, in which one of the partner's characteristic is visual impairment, is undoubtedly the preparation for family life. In the case of people with profound visual impairment, the sex education program is not enough, because knowledge about the characteristics of intimate human life should be correlated with mental, social and functional preparation for undertaking tasks of the period of adulthood.

people; 3) Later interest in sexual activity may have been a result of less social activity; 4) Answers given to the questions of the survey questionnaire raised doubts as to whether people with a disability had sufficiently reliable knowledge about the methods of conscious parenthood planning; 5) Youth with visual impairment should be provided with age-appropriate sex education containing relevant methods and materials adapted to their perceptive abilities; 6) Subsequent research should provide information on the design of effective sex education curricula and appropriate tools and techniques for those activities that will bring benefit to young people with visual impairment (C. Krupa and S. Esmail, 2010), warning against undertaking premature and risky sexual behaviours.

53 W.S. Pava, Visually impaired persons' vulnerability to sexual and physical assault, AFB “Journal of Visual Impairment \& Blindness” 1994, no. 88, pp. 103-112; W.S. Pava (1994), a clinical psychologist from the Department of Veterans Affairs (Tacoma, USA), found in the conducted studies that factors such as impaired mobility (hindered fight or flight attempt), inability to identify attackers, less access to safety measures, use of less common means of transport (a taxi) or the occasional need of help from sighted people during independent travel can cause a person with a visual impairment (female or male) to become the target of sexual or physical assault. M. Oczkowska (1958), in one of the first Polish studies concerning plans for family life and its reality based on the stories of blind women, described cases of abuse in the form of: offensive insults or dirty jokes, proposals with sexual overtones, assaults under the guise of help, sexual abuse resulting in an unplanned pregnancy. All those acts were committed by able-bodied men towards women with visual impairment. 


\section{Conclusion}

The limited framework of this study did not allow for raising a number of issues from the area of further interdisciplinary perspective, which are a condition for the personal and parental success of people with visual impairment. The first of them is the insufficient availability of rehabilitation training and the latest rehabilitation technologies, which serve to equalise life chances. The level of vocational skills and the opportunity to find one's place on the labour market also seem to be a separate issue. This is because financial and housing independence are the basis for starting an independent life. The second area of difficulties is the social sphere, which includes: social attitudes reluctant to family life and parenthood of people with disabilities, still existing barriers in access to public space or insufficient involvement of the non-government organizations sector in diagnosing the needs of special families, creating support groups and lobbying for their benefit. ${ }^{54}$

The last issue comprises the deficiencies in building a reliable image of parenting of people with disabilities in the media. These above-mentioned issues will be the subject of analysis in subsequent studies.

\section{Bibliography}

[1] Allport G.W., Personalisty: a psychological interpretation, H. Holt, New York 1937.

[2] Bakiera L., Petnienie ról rodzicielskich a rozwój dorostych w wieku średnim, „Psychologia Rozwojowa" 2004, vol. 9 no. 2, pp. 37-46.

[3] Bakiera L., Zaangażowane rodzicielstwo a autokreacyjny aspekt rozwoju dorostych, Wydawnictwo Difin S.A., Warsaw 2013.

[4] Bojarska A., Uwarunkowania macierzyństwa kobiet niewidomych $i$ stabowidzacych, [in:] „Kobiecość a niepełnosprawność”, ed. W. Janocha, K. Zielińska-Król, Wydawnictwo KUL, Lublin 2015, pp. 67-83.

${ }^{54} \mathrm{M}$. Wałachowska, Edukacja i rehabilitacja osób niewidomych $i$ stabowidzacych $w$ działalności organizacji pozarządowych $i$ wybranych instytucji rzadowych III RP, Faculty of Educational Sciences, Maria Grzegorzewska University, Warsaw 2010, pp. 149228, unpublished doctoral dissertation. 
[5] Bronfenbrenner U., The ecology of human development: Experiments by nature and design, Harvard University Press, Cambridge 1979.

[6] Bulkowski K., Federowicz M., Grajkowski W., Kaczan R., Maliszewska K., Marszał D., Męziński M., Poziomek U., Rycielski P., Walczak D., Wichrowski A., Opinie $i$ oczekiwania młodych dorostych (osiemnastolatków) oraz rodziców dzieci $w$ wieku szkolnym wobec edukacji dotyczacej rozwoju psychoseksualnego i seksualności. Raport z badania, Educational Research Institute, Warsaw 2015.

[7] Czerwińska K., Kucharczyk I., Tyflopsychologia, Wydawnictwo Naukowe PWN, Warsaw 2019.

[8] Długosz-Kurczabowa K. (ed.), Wielki Słownik Etymologiczno-Historyczny Jezyka Polskiego, Wydawnictwo Naukowe PWN, Warsaw 2008.

[9] Dubisz S. (ed.), Uniwersalny Stownik Jezzyka Polskiego, vol. 3, Wydawnictwo Naukowe PWN, Warsaw 2003.

[10] Duracz-Walczakowa A., Wybrane problemy życia rodzinnego niewidomych, "Studia Socjologiczne" 1966, no. 1, pp. 213-238.

[11] Erikson E.H., Identity: Youth and crisis, W.W. Norton \& Company, Inc., New York - London 1968.

[12] Fernández R., Rola ojca, "Communio. Międzynarodowy Przegląd Teologiczny" 1999, no. 2, pp. 99-124.

[13] Fornalik I., Edukacja seksualna osób niepetnosprawnych. Notatki na marginesach ministerialnych rozporządzeń, „Kwartalnik Pedagogiczny” 2010, no. 2, pp. 103-119.

[14] Fraszka E., Oleksiak E., Być mama, być Tatą. Poradnik dla niewidomych rodziców, Polish Association of the Blind, Warsaw 2017.

[15] Górnicka B., Pomimo niepetnosprawności... - wybrane aspekty rodzicielstwa w różnych fazach funkcjonowania rodziny $z$ problemem niepetnej sprawności dziecka lub rodzica, [in:] Rodzicielstwo w różnych fazach rozwoju rodziny, ed. J. Brągiel, B. Górnicka, Wydawnictwo Uniwersytetu Opolskiego, Opole 2017, pp. 73-88.

[16] Gurba E., Wczesna dorosłość, [in:] „Psychologia rozwoju człowieka. Charakterystyka okresów życia człowieka”, ed. B. Harwas-Napierała, J. Trempała, Wydawnictwo Naukowe PWN, Warsaw 2008, pp. 202-233.

[17] Harwas-Napierała B., Zmiany w funkcjonowaniu rodziny $i$ ich konsekwencje dla rozwoju rodziców, [in:] „Rodzina a rozwój człowieka dorosłego”, ed. B. Harwas-Napierała, Wydawnictwo Naukowe Uniwersytetu im. Adama Mickiewicza, Poznań 2003, pp. 11-23.

[18] Havighurst R.J., Developmental tasks and education, Longman, New York London 1981.

[19] Jabłoński D., Ostasz D., Zarys wiedzy o rodzinie, małżeństwie, kohabitacji i konkubinacie. Perspektywa antropologii kulturowej i ogólnej, Wydawnictwo Adiaphora, Olsztyn 2001.

[20] Kapperman G., Brown-Ogilvie T., Yesaitis J., Peskin A., Prevention of sexual assault against children who are visually impaired, "Division on Visual Impairments Quarterly" 2014, no. 59(2), pp. 33-38. 
[21] Kapperman G., Page K., Kelly S., Finding the One: Human mate selection applied to persons who are visually impaired, "Division on Visual Impairments Quarterly" 2014, no. 59(2), pp. 38-45.

[22] Kawka J., Warunki wychowawcze dzieci w rodzinach inwalidów wzroku, Wydawnictwo UMCS, Lublin 1996.

[23] Kelly S.M., Kapperman G., Sexual activity of young adults who are visually impaired and the need for effective sex education, AFB "Journal of Visual Impairment \& Blindness" 2012, no. 106, pp. 519-526.

[24] Kornas-Biela D., Postawy spoteczne wobec matżeństwa $i$ macierzyństwa kobiet z niepetnosprawnościa, [in:] „Kobiecość a niepełnosprawność”, ed. W. Janocha, K. Zielińska-Król, Wydawnictwo KUL, Lublin 2015, pp. 18-48.

[25] Kotowski S., Przewodnik po problematyce osób niewidomych $i$ stabowidzących, Foundation of the Polish Blind and Visually Impaired "Trakt", State Fund for Rehabilitation of Disabled People, Warsaw 2008.

[26] Kozielecki J., Koncepcja transgresyjna człowieka, PWN, Warsaw 1987.

[27] Krupa C., Esmail S., Sexual health education for children with visual impairments: Talking about sex is not enough, AFB "Journal of Visual Impairment \& Blindness" 2010, no. 104, pp. 327-337.

[28] Kwak A., Rodzicielstwo - przejaw społecznej wspótzależności, [in:] „Rodzicielstwo między domem, prawem, służbami społecznymi", ed. A. Kwak, Wydawnictwo Akademii Pedagogiki Specjalnej, Warsaw 2008, pp. 7-39.

[29] Kwak A., Rozwojowy charakter rodzicielstwa - podstawowe zakresy zmian, [in:] „Rodzicielstwo w różnych fazach rozwoju rodziny”, ed. J. Brągiel, B. Górnicka, Wydawnictwo Uniwersytetu Opolskiego, Opole 2017, pp. 37-49.

[30] M. Orłowska, B. Sobczyk, Wspótczesny obraz rodziny - hit czy kit?, [in:] „Rodzicielstwo $\mathrm{w}$ sytuacji dezorganizacji rodziny i możliwości wspomagania rodziców", ed. J. Brągiel, B. Górnicka, Wydawnictwo Uniwersytetu Opolskiego, Opole 2014, pp. 17-26.

[31] Majewski T., Psychologia niewidomych i niedowidzacych, Państwowe Wydawnictwo Naukowe, Warsaw 1983.

[32] Matuszewska M., Funkcjonowanie w rolach rodzicielskich jako źródło rozwoju młodych dorostych, [in:] „Rodzina a rozwój człowieka dorosłego”, ed. B. Harwas-Napierała, Wydawnictwo Naukowe Uniwersytetu im. Adama Mickiewicza, Poznań 2003, pp. 25-46.

[33] Matuszewska M., Petnienie społecznych ról rodzinnych przez młodych dorostych i ich rozwój indywidualny, [in:] „Rodzina a rozwój jednostki”, ed. M. Tyszkowa, Centralny Program Badań Podstawowych CPBP, Poznań 1990, pp. 75-87.

[34] Obuchowski K., Psychologia dążeń ludzkich, PWN, Warsaw 1966.

[35] Oczkowska M., Sytuacja niewidomej kobiety. A typescript of the paper presented during the Conference of the Polish Association of the Blind, PZN, Muszyna 1958.

[36] Ossowski R., Kształtowanie obrazu własnej sytuacji i siebie u inwalidów wzroku w procesie rehabilitacji, Wydawnictwo Uczelniane WSP Bydgoszcz, Bydgoszcz 1982. 
[37] Pava W.S., Visually impaired persons' vulnerability to sexual and physical assault, AFB “Journal of Visual Impairment \& Blindness” 1994, no. 88, pp. 103-112.

[38] Pervin L.A., Psychologia osobowości, Gdańskie Wydawnictwo Psychologiczne, Gdańsk 2002.

[39] Regulation of the Minister of National Education of 12 August 1999 on the method of school teaching and the scope of content regarding knowledge on the sexual life of an individual, principles of conscious and responsible parenthood, the value of the family, life in the prenatal phase, as well as on methods and measures of conscious procreation contained in the general education program (Journal of Laws 1999, no. 67, item 756).

[40] Regulation of the Minister of National Education of 28 March 2017 on the outline timetables in public schools, in particular (Journal of Laws 2017, item 703).

[41] Tyszkowa M., Jednostka a rodzina: interakcje, stosunki, rozwój, [in:] „Psychologia rozwoju człowieka. Zagadnienia ogólne", eds. M. Przetacznik-Gierowska, M. Tyszkowa, Wydawnictwo Naukowe PWN, Warsaw 2009, pp. 124-150.

[42] Wałachowska M., Edukacja i rehabilitacja osób niewidomych $i$ stabowidzacych $w$ działalności organizacji pozarzadowych $i$ wybranych instytucji rzadowych III RP, Faculty of Educational Sciences, Maria Grzegorzewska University, Warsaw 2010, unpublished doctoral dissertation.

[43] Waszczak S., Stosunek spoteczeństwa do osób niepetnosprawnych, „Problemy Polityki Społecznej" 2000, no. 2, pp. 89-99.

[44] Wawrocka A., Krawczyński M., Genetyka w okulistyce, [in:] „Okulistyka”, eds. A. Grzybowski, Edra Urban \& Partner, Wrocław 2018, pp. 305-314.

[45] Zaorska M., Etyka a problematyka seksualności osób z poważnymi, głębokimi niepetnosprawnościami, „Niepełnosprawność i Rehabilitacja” 2018, no. 1, pp. 42-53. 